\title{
He Jiahong, Back From the Dead: Wrongful Convictions and Criminal Justice in China,
} Honolulu,University of Hawai'i Press,2016, xxvi, 236 pp.

Stanley Lubman

\section{OpenEdition}

\section{Journals}

Electronic version

URL: http://journals.openedition.org/chinaperspectives/7150

DOI: $10.4000 /$ chinaperspectives. 7150

ISSN: 1996-4617

\section{Publisher}

Centre d'étude français sur la Chine contemporaine

Printed version

Date of publication: 1 December 2016

Number of pages: 92

ISSN: 2070-3449

\section{Electronic reference}

Stanley Lubman, « He Jiahong, Back From the Dead: Wrongful Convictions and Criminal Justice in China, », China Perspectives [Online], 2016/4 | 2016, Online since 01 December 2016, connection on 24 September 2020. URL : http://journals.openedition.org/chinaperspectives/7150 ; DOI : https://doi.org/ 10.4000/chinaperspectives.7150 


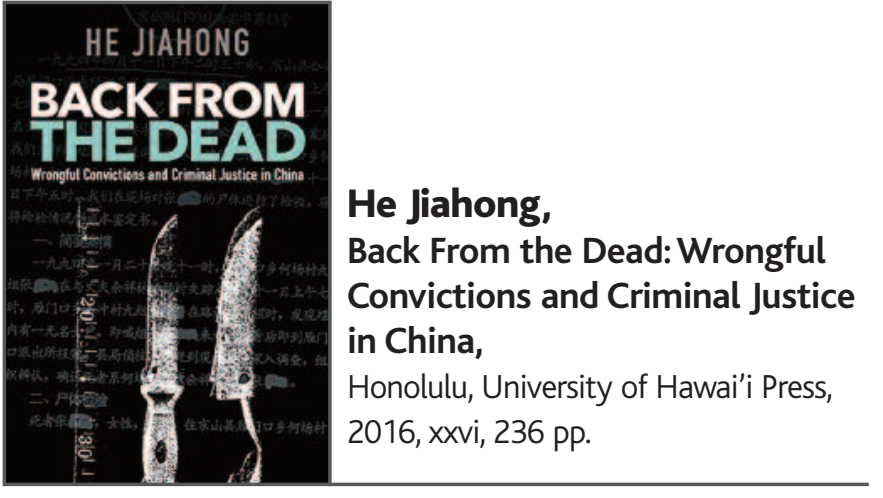

\section{STANLEY LUBMAN}

n 1987, Teng Xingshan was sentenced to death for raping a woman and dismembering her body; wrongfully convicted, he was executed in 1989 - but in 1992 the "victim" returned home, and Teng was exonerated in 2005. His case is only one among numerous other tragic wrongful convictions discussed in Back From the Dead: Wrongful Convictions and Criminal Justice in China, by Professor He Jiahong (Renmin University Law School, Beijing). This book, the product of ten years of research, is a scholarly analysis of wrongful convictions that demonstrates deep system-wide flaws in China's criminal justice system.

Professor He is one of China's best-known experts on criminal law. His book begins with a list of 17 "principal cases of wrongful conviction in China" from 1987 to 2014 (p. xxv), and he analyses some of them in depth. Moreover, he concludes his book with forceful argument for necessary reforms - which can be implemented only if and when a powerful Chinese leadership fosters a change in the "mentalities" of officials and the public.

Two empirical studies of wrongful convictions were used in his research. One was a questionnaire sent to legal professionals (in the police, procuracies, courts, law firms, and justice departments) in 19 regions in China; the other was a questionnaire also sent to judges, procurators, police, and lawyers in Beijing and four other regions. The first survey led to the conclusion that "evidential mistakes" are the major causes of wrongful convictions, because of "insufficient professional qualities of investigators, extortion of confessions by torture, and backwardness of facilities and techniques." The second survey concludes that false witness testimony was a "main cause" of wrongful convictions along with torture and false confession of the accused (pp. 5-6).

The author's analysis makes the book an excellent source for use in courses, not only on Chinese law but on Chinese political culture as well. Clearly written and easily accessible, it will serve as a good companion to another authoritative book based on empirical research, Criminal Justice in China: An Empirical Inquiry, (Michael McConville (ed.), Cheltenham, UK, Northampton, MA, Edward Elgar Publishing, 2011).

Professor He points to the principal problems that place far greater emphasis on fighting crime than on protecting the rights of the accused: police domination of the criminal investigation, excessively tight deadlines for concluding criminal cases, one-sided collection of evidence, frequent misinterpretations of scientific evidence, the use of torture to obtain confessions, the superficiality of court trials, unlawfully extended custody, and the use of reduced sentences rather than acquittal in cases of doubt.
Professor He forcefully criticises one failure of the process, well-known but uncorrected: the Criminal Procedure Law provides that the three institutions that administer the criminal process - police, procuracy, and courts - should work independently of each other. In practice, however, these three cooperate closely. For example, prosecutors treat arrest warrants as a mere formality because they wish "to maintain harmony with the investigators" (p. 50). In addition, difficult cases are referred to Party political-legal work committees at each level of government that place excessive emphasis on coordination of efforts among the three agencies involved rather than on their independent review.

Professor He condemns the one-sidedness of criminal proceedings in which "evidence of guilt is admitted without question, regardless of its truth or falsity" (p. 69). In practice, he writes, most cases of torture and forced confessions "go unpunished due to lack of evidence" (p. 44).

Because of the emphasis on obtaining confessions and maintaining a high rate of case closure, arrests precede collection of evidence. By the time a court must issue a decision, it is only "a figure-head." As a result, courtroom trials, in Professor He's words, "are now a mere formality" (p. 117).

His analysis ventures further as he points to the "mentalities" of the officials involved, citing their "military mind-set and traditions" (p. 14). In the concluding chapters he summarises his outspoken views on nothing less than changing those mentalities in order to increase procedural justice throughout the system.

Research demonstrates that new rules adopted for exclusion of confessions or statements based on illegally obtained evidence, physical evidence, or statements of a witness or victim have not been satisfactorily applied exposing a critical "gap between the law on paper and the law in action" (p. 155). He adds that the Criminal Procedure Law fails to establish a defendant's rights to silence despite a provision that "no one shall be compelled to prove his or her guilt" (p. 157). Professor He's book is timely: an opinion on a "Trial-Centred Criminal Procedure System" has recently been issued by the highest-level authorities of the courts and prosecutors along with the Ministries of Public Security, National Security, and Justice. (1) Among the stated goals is the need to base guilty verdicts on evidence that establishes a crime beyond "reasonable doubt" and that has been lawfully gathered. Evidence gathered through "extortion of confessions" must be excluded. The rules are too extensive to be discussed in detail here, but at the core is the call to "complete systems safeguarding the rights of parties, defenders, and other litigation participants."

Centring the criminal process on the trial, one of the key reforms urged by Professor He, is likewise an aim of the new rules, which, if well implemented, would move toward strengthening procedural justice in the criminal process.

In a vigorous "Postscript," Professor He cites with approval the communique of the Party Central Committee in October 2014, calling for advancing the rule of law in China. He ventures beyond that formulaic language, arguing that there is a basic need to develop the "habit" of rule by law, which is currently weak. Government officials must become role models for the public, but "many officials continue to think that power stands above the law" (p. 208).

Also, laws are often overlooked because of the influence of guanxi. Law in "real life" is needed, "and the place it holds in the eyes of the people" (p. 208). The author ends his book at this point, doubtless because it is impossible today to predict when the tight authoritarianism of government under the current leadership might be loosened. In the meantime, Professor He's 